\title{
GROUNDWATER QUALITY ASSESSMENT OF WELLS IN IFEWARA, OSUN STATE
}

A. M. GBADEBO, M. O. ADEYEMI AND A. B. OLADIPUPO

(Received 1 February 2017; Revision Accepted 10 November 2017)

\begin{abstract}
Study was carried out in Ifewara, Osun state with an objective of evaluating the quality and suitability of local groundwater for domestic purposes. Twenty six groundwater samples from hand dug wells and one borehole sample and were subjected to physicochemical analysis. Results from the study shows that the cationic and anionic concentrations vary as follows: $\mathrm{Na}^{+}(0.2-3.5 \mathrm{mg} / \mathrm{l}), \mathrm{K}^{+}(0.1-15.1 \mathrm{mg} / \mathrm{l}) \mathrm{Ca}^{2+}(16-96 \mathrm{mg} / \mathrm{l}), \mathrm{HCO}_{3}^{-}(16-176 \mathrm{mg} / \mathrm{l}), \mathrm{Mg}^{2+}(3-$ $104 \mathrm{mg} / \mathrm{l}), \mathrm{NO}_{3}{ }^{-}(0.18-11.43 \mathrm{mg} / \mathrm{l}), \mathrm{SO}_{4}{ }^{2-},(1.24-21.3 \mathrm{mg} / \mathrm{l}), \mathrm{Cl}^{-}(2-52 \mathrm{mg} / \mathrm{l})$, and $\mathrm{PO}_{4}(0.01-0.75 \mathrm{mg} / \mathrm{l})$. The study also shows that the water is fresh with TDS value (avg. $93.8 \mathrm{mg} / \mathrm{l}$ ) and a neutral $\mathrm{pH}$ (avg. 6.8) within the permissible range $(6.5-8.5)$.Hydrogeochemical evaluation of the groundwater reveals that it is predominantly of the $\mathrm{CaHCO}_{3}$ type while others belong to the Mixed $\mathrm{CaMgCl}$ type. The water chemistry was observed to have been influenced by the dilution and weathering processes at shallow depth.
\end{abstract}

KEYWORDS: Groundwater quality, fresh water, hydrogeochemical evaluation,

\section{INTRODUCTION}

Sustainable provision of portable and adequate water resource for immediate and future use are of regional to global concern. Water supports all forms of life (Vanloon and Duffy, 2005) and the challenge of obtaining clean portable water is a concern for most people living in the rural area in most developing countries. The quality of water available for the population is often a function of natural as well as anthropogenic activities (Sajjad, et al., 1998).

Water is sourced from two principal sources; surface waters such as fresh water lakes, rivers, streams, etc. and ground water such as borehole and well water. Groundwater refers to underground fresh water which can be abstracted for domestic, agricultural and industrial uses and it accounts for $98 \%$ of the world's fresh water (Buchanan, 1983; Bouwer, 2002). Fresh water resource in most communities is under threat due to immense natural and anthropogenic influences as a result of factors such as overpopulation and activities (including agriculture, indiscriminate refuse disposal and use of septic tanks, soak away and latrines) which are capable of producing run-offs and leachate which could infiltrate into and pollute groundwater formation.

Many households depend on wells due to the frequent interruptions or non-availability of supply of treated water. The aim of this study is to investigate the water quality and hydrogeochemical process (evolution, origin and mixing) of water resource in Ifewara.

A. M. Gbadebo, Department of Environmental Management and Toxicology, Federal University of Agriculture Abeokuta, Abeokuta, Nigeria.

M. O. Adeyemi, Department of Geology, Crawford University, Igbesa, Nigeria.

A. B. Oladipupo, Department of Environmental Management and Toxicology, Federal University of Agriculture Abeokuta, Abeokuta, Nigeria.

(C) 2018 Bachudo Science Co. Ltd. This work is licensed under Creative Commons Attribution 4.0 International license. 


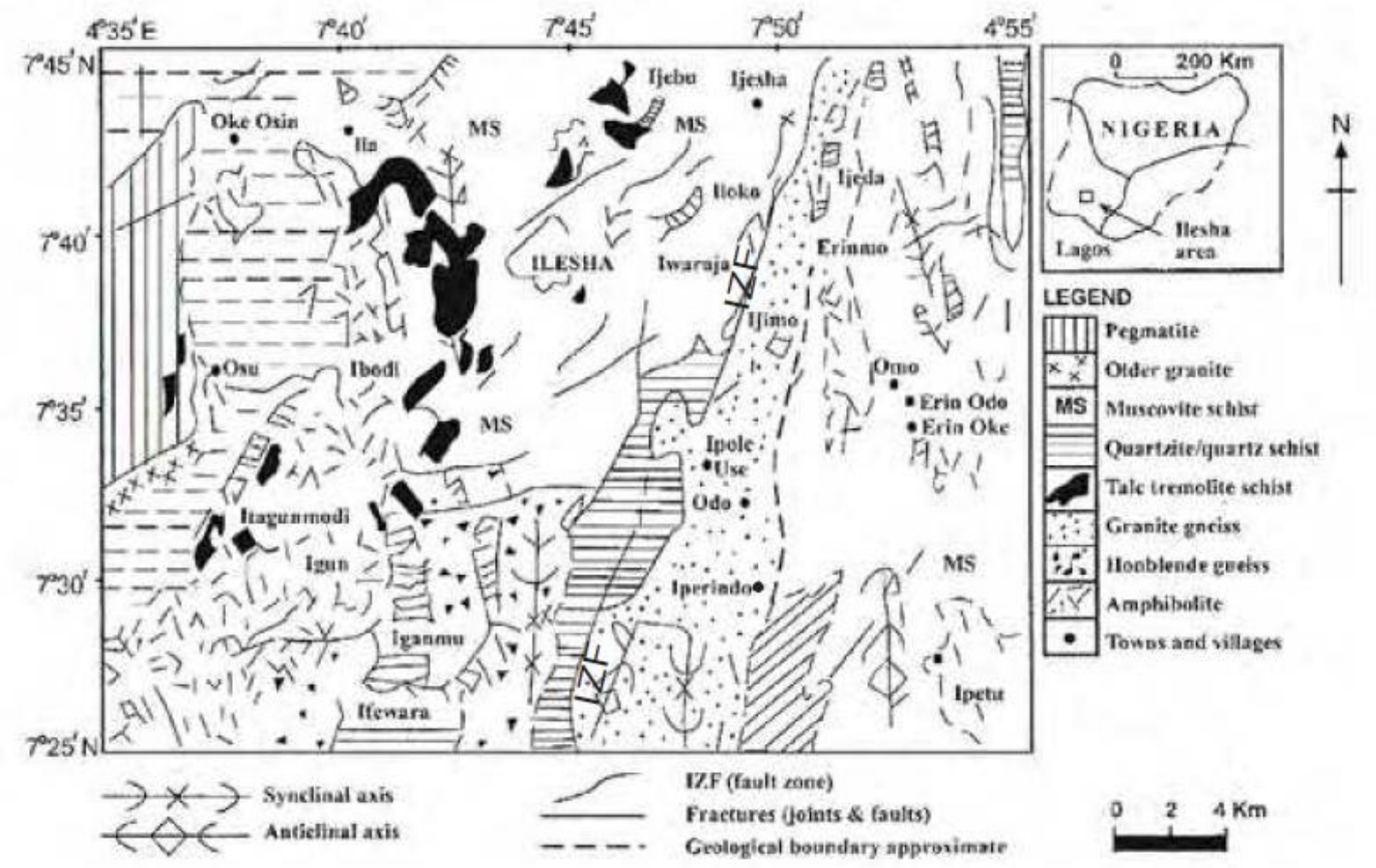

Figure 1: Geologic map of llesha schist belt showing Ifewara

\subsection{Study Area}

The study area in located in Atakumosa local government area of Osun State, Southwestern Nigeria. It covers an area of approximately $14,875 \mathrm{Km}^{2}$. The study area enjoys a tropical climate with distinct wet and dry seasons. Ifewara falls within the llesha schist belt and it is underlained by gneiss, migmatite and metasediments ranging from Precambrian to Paleozoic age (Fig. 1).

\subsection{Methodology}

Field investigation of groundwater samples were carried out on water samples from 25 hand dug wells and one borehole samples in Ifewara. A pair of samples were collected in carefully rinsed and labelled bottles for both cationic and anionic analyses. Dilute Nitric acid was added to the samples for cationic analysis on the site to preserve and retard the chemical and metal changes while the anions were preserved with ice blocks. Hydrogeochemical properties of representative samples from the wells such as; temperature, $\mathrm{pH}$, Electrical Conductivity (EC) and total dissolved solids(TDS)were measured on the field using Hanna 98130 digit multi- meter. The concentration of cation species such as $\mathrm{Ca}^{2+}$ $, \mathrm{Mg}^{2+}, \mathrm{K}$ and $\mathrm{Na}$ in the samples were determine with the use of spectrophotometer while the Anions; $\mathrm{SO}_{4}{ }^{2-}$, $\mathrm{HCO}_{3}{ }^{-}, \mathrm{Cl}^{-}$and $\mathrm{NO}_{3}$ were determined using digital titration method.

Data from the hydrogeochemical analysis were subjected to statistical analysis in order to classify the water resource into distinct group and sub-groups. Water quality assessment were also carried out by comparing the results against WHO standards for domestic use.

\subsection{RESULTS AND DISCUSSION}

The results of the physiochemical parameters determined for water samples in the study area are presented in Table 1. The range concentration of $\mathrm{Na}^{+}$, $\mathrm{K}^{+}, \mathrm{Ca}^{2+}, \mathrm{HCO}_{3}{ }^{-}, \mathrm{Mg}^{2+}, \mathrm{NO}_{3}{ }^{-}, \mathrm{SO}_{4}{ }^{2-}, \mathrm{Cl}^{-}$, and $\mathrm{PO}_{4}$ values are 0.2-3.5 mg/l, 0.1-15.1 mg/l, 16-96 mg/l, 16-176 mg/l, 3-104 mg/l, 0.18-11.43 mg/l, 1.24-21.3 mg/l, 2-52 mg/l, $0.01-0.75 \mathrm{mg} / \mathrm{l}$, respectively. Fig 2 and 3 represent the variation diagrams of ionic species in the groundwater of the study area. A plot of TDS vs ionic ratios Gibbs plot and Durov diagram is shown in Fig 4 and Fig 5. 
Table 1: Physicochemical parameters of groundwater samples in Ifewara ( $\mathrm{mg} / \mathrm{L}$ )

\begin{tabular}{|c|c|c|c|c|c|c|c|c|c|c|c|c|c|c|c|}
\hline & $\mathrm{Ca}$ & Mg & $\mathrm{Na}$ & $\mathbf{K}$ & $\begin{array}{r}\mathrm{HCO}_{3} \\
(\mathrm{~m}\end{array}$ & $\mathrm{SO}_{4}$ & $\mathrm{Cl}$ & $\mathrm{NO}_{3}$ & $\mathrm{PO}_{4}$ & TDS & $\mathrm{pH}$ & $\begin{array}{l}\mathrm{EC} \\
(\mu \mathrm{S} / \mathrm{cm})\end{array}$ & SAR & Water Type & $\mathrm{SH}$ \\
\hline A1 & 28 & 44 & 22 & 2 & 72 & 10.8 & 1.1 & 1.36 & 0.01 & 71 & 7.35 & 149 & 0.603 & $\mathrm{Mg}-\mathrm{HCO}_{3}$ & LOW \\
\hline A2 & 96 & 80 & 36 & 9.1 & 176 & 15 & 2.4 & 1.36 & 0.11 & 224 & 6.96 & 457 & 0.656 & $\mathrm{Mg}-\mathrm{HCO}_{3}$ & MEDIUM \\
\hline A3 & 84 & 80 & 18 & 12 & 164 & 10.97 & 3.2 & 1.27 & 0.03 & 244 & 6.8 & 495 & 0.337 & $\mathrm{Mg}-\mathrm{HCO}_{3}$ & MEDIUM \\
\hline A4 & 56 & 8 & 16 & 9.2 & 64 & 10.32 & 2 & 4.08 & 0.01 & 134 & 6.59 & 277 & 0.529 & $\mathrm{Ca}-\mathrm{HCO}_{3}$ & MEDIUM \\
\hline A5 & 52 & 16 & 52 & 15.1 & 68 & 9.84 & 3.2 & 1.63 & 0.25 & 191 & 6.55 & 391 & 1.62 & $\mathrm{Ca}-\mathrm{HCO}_{3}$ & MEDIUM \\
\hline A6 & 84 & 40 & 14 & 7.3 & 124 & 12.58 & 2.5 & 1.9 & 0.73 & 116 & 6.92 & 244 & 0.314 & $\mathrm{Ca}-\mathrm{HCO}_{3}$ & LOW \\
\hline A7 & 40 & 12 & 8 & 0.5 & 52 & 7.56 & 0.8 & 2.54 & 0.75 & 52 & 6.82 & 105 & 0.284 & $\mathrm{Ca}-\mathrm{HCO}_{3}$ & LOW \\
\hline A8 & 52 & 8 & 16 & 0.2 & 60 & 8.54 & 0.6 & 5.26 & 0.05 & 58 & 6.67 & 121 & 0.545 & $\mathrm{Ca}-\mathrm{HCO}_{3}$ & LOW \\
\hline A9 & 24 & 12 & 6 & 0.1 & 36 & 5.97 & 0.2 & 6.62 & 0.01 & 35 & 6.71 & 73 & 0.249 & $\mathrm{Ca}-\mathrm{HCO}_{3}$ & LOW \\
\hline A10 & 16 & 16 & 6 & 0.5 & 32 & 7.56 & 1.4 & 2.18 & 0.01 & 29 & 6.55 & 62 & 0.253 & $\mathrm{Ma}-\mathrm{HCO}_{3}$ & LOW \\
\hline A11 & 44 & 3 & 12 & 4.5 & 44 & 11.29 & 1.2 & 1.45 & 0.01 & 88 & 6.37 & 184 & 0.472 & $\mathrm{Ca}-\mathrm{HCO}_{3}$ & LOW \\
\hline A12 & 24 & 24 & 4 & 0.3 & 48 & 7.26 & 0.3 & 1.27 & 0.27 & 25 & 6.36 & 51 & 0.138 & $\mathrm{Mg}-\mathrm{HCO}_{3}$ & LOW \\
\hline A13 & 40 & 56 & 8 & 4.5 & 92 & 1.24 & 1.4 & 4.26 & 0.35 & 55 & 6.57 & 116 & 0.191 & $\mathrm{Mg}-\mathrm{HCO}_{3}$ & LOW \\
\hline A14 & 40 & 32 & 20 & 4.6 & 72 & 8.06 & 3.5 & 6.35 & 0.22 & 155 & 6.29 & 328 & 0.571 & $\mathrm{Mg}-\mathrm{HCO}_{3}$ & MEDUIM \\
\hline A15 & 56 & 104 & 20 & 5 & 160 & 9.35 & 2.3 & 1.9 & 0.01 & 125 & 6.74 & 255 & 0.365 & $\mathrm{Mg}-\mathrm{HCO}_{3}$ & MEDIUM \\
\hline A16 & 76 & 28 & 16 & 2.4 & 104 & 21.13 & 2 & 11.43 & 0.13 & 162 & 7.2 & 338 & 0.398 & $\mathrm{Ca}-\mathrm{HCO}_{3}$ & MEDIUM \\
\hline A17 & 48 & 20 & 18 & 4.5 & 68 & 7.74 & 2.5 & 2.63 & 0.01 & 130 & 7.3 & 269 & 0.55 & $\mathrm{Ca}-\mathrm{HCO}_{3}$ & MEDIUM \\
\hline A18 & 44 & 28 & 2 & 8 & 72 & 8.22 & 2 & 1.81 & 0.03 & 90 & 7.33 & 187 & 0.579 & $\mathrm{Mg}-\mathrm{HCO}_{3}$ & LOW \\
\hline A19 & 48 & 36 & 20 & 3.5 & 84 & 18.87 & 1.3 & 0.18 & 0.29 & 130 & 6.89 & 269 & 0.531 & $\mathrm{Mg}-\mathrm{HCO}_{3}$ & MEDIUM \\
\hline A20 & 56 & 12 & 22 & 0.8 & 68 & 7.74 & 2.5 & 0.36 & 0.03 & 126 & 6.84 & 259 & 0.695 & $\mathrm{Ca}-\mathrm{HCO}_{3}$ & MEDIUM \\
\hline A21 & 24 & 12 & 8 & 0.7 & 36 & 7.72 & 1.3 & 0.41 & 0.24 & 59 & 7.33 & 116 & 0.332 & $\mathrm{Ca}-\mathrm{HCO}_{3}$ & LOW \\
\hline A22 & 24 & 10 & 8 & 0.5 & 24 & 9.19 & 1.5 & 4.08 & 0.03 & 25 & 6.53 & 52 & 0.346 & $\mathrm{Ca}-\mathrm{HCO}_{3}$ & LOW \\
\hline A23 & 16 & 12 & 6 & 0.4 & 16 & 8.71 & 1.6 & 3.09 & 0.01 & 14 & 6.96 & 29 & 0.276 & $\mathrm{Mg}-\mathrm{HCO}_{3}$ & LOW \\
\hline A24 & 20 & 10 & 10 & 0.4 & 20 & 3.39 & 1.6 & 4.35 & 0.01 & 15 & 6.8 & 26 & 0.455 & $\mathrm{Ca}-\mathrm{HCO}_{3}$ & LOW \\
\hline A25 & 28 & 10 & 6 & 1.5 & 24 & 8.87 & 1.2 & 0.63 & 0.06 & 24 & 6.97 & 50 & 0.247 & $\mathrm{Ca}-\mathrm{HCO}_{3}$ & LOW \\
\hline A26 & 16 & 4 & 10 & 1.7 & 20 & 11.45 & 1.4 & 2.63 & 0.29 & 46 & 6.75 & 93 & 0.578 & $\mathrm{Ca}-\mathrm{SO}_{4}$ & LOW \\
\hline Avg. & 43.69 & 27.58 & 14.77 & 3.82 & 69.23 & 9.59 & 1.73 & 2.89 & 0.15 & 93.19 & 6.81 & 192.15 & 0.47 & & \\
\hline Min & 16.00 & 3.00 & 2.00 & 0.10 & 16.00 & 1.24 & 0.20 & 0.18 & 0.01 & 14.00 & 6.29 & 26.00 & 0.14 & & \\
\hline Max & 84.00 & 104.00 & 52.00 & 15.10 & 164.00 & 21.13 & 3.50 & 11.43 & 0.75 & 244.00 & 7.33 & 495.00 & 1.62 & & \\
\hline
\end{tabular}

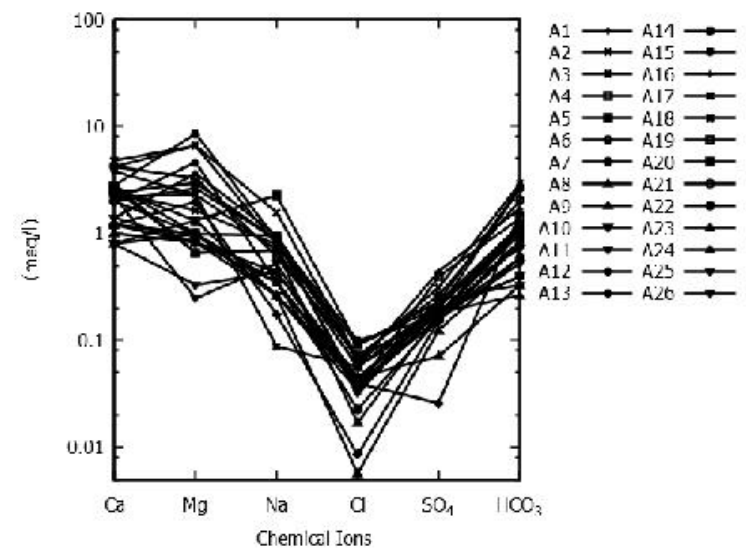

Figure 2: Variation diagram of the ionic species in the water samples 


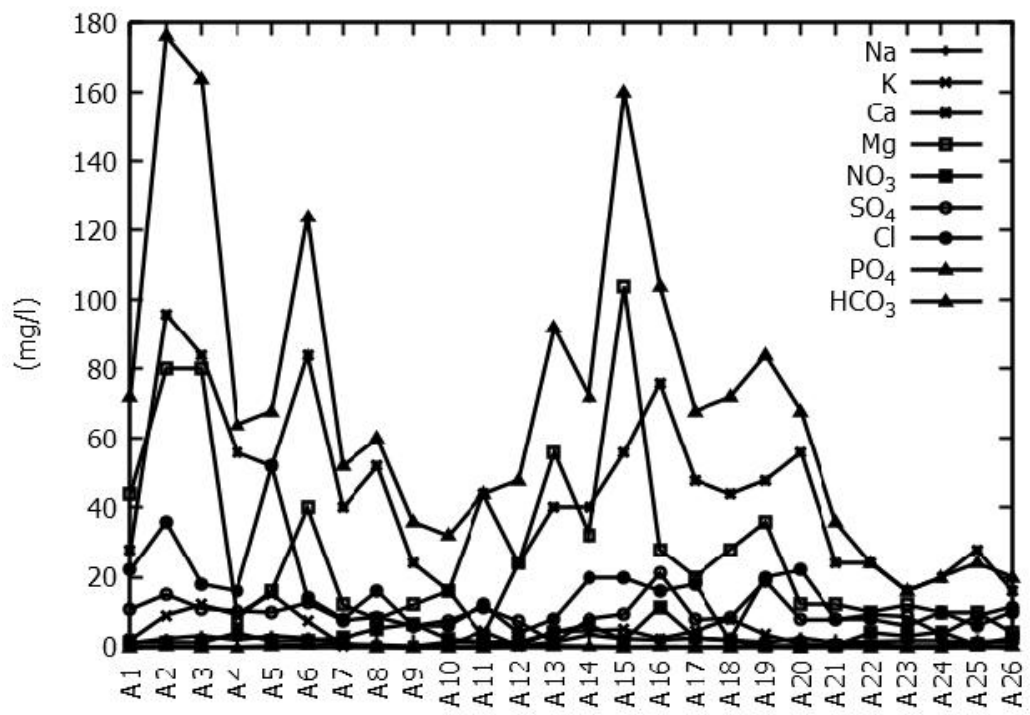

Sample Numbers

Figure 3: Scholler diagram of Chemical ions

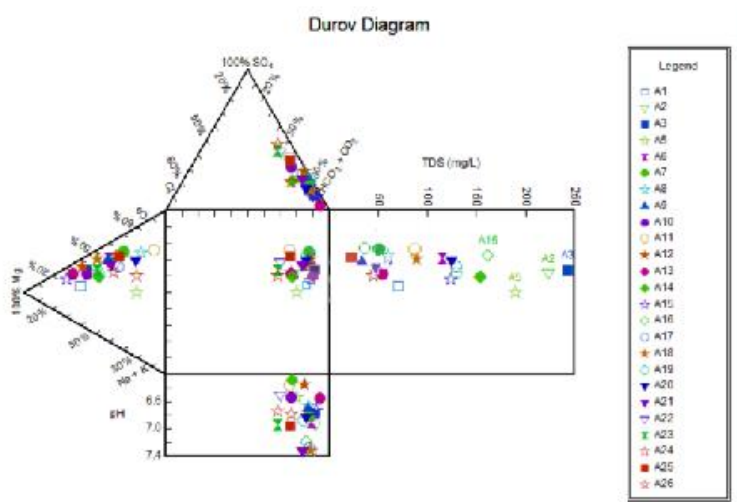

Figure 4: Durov diagram

The physical description of the water is clear and colorless. The $\mathrm{pH}$ values of water samples is neutral (varying between 6.3 and 7.4, avg. 6.8) and it falls within the limits $(6.5-8.5)$ recommended for drinking water WHO (2006).However samples A11, A12 and A14 are slightly acidic with $\mathrm{pH}$ of $6.37,6.36$ and 6.29 respectively. Electrical conductivity signifies the amount of total dissolved solids and it is the most important parameter to identify salinity and suitability of water for irrigation purposes (Ramesh and Bhuvana, 2012). The EC values in the water ranges between26 to $495 \mu \mathrm{S} / \mathrm{cm}$.

The hydrogeochemistry of the water was evaluated by plotting the concentrations of the major ions such as $\mathrm{Na}^{+}, \mathrm{K}^{+}, \mathrm{Ca}^{2+}, \mathrm{HCO}_{3}{ }^{-}, \mathrm{Mg}^{2+}, \mathrm{SO}_{4}{ }^{2-}$ and Clin milli-equivalent per liter in a Piper diagram (1994) using Rock Ware AqQA software. The result show that the samples plotted in fields that suggesting the facies type of the water are predominantly $\mathrm{CaHCO}_{3}$ type while the others are of Mixed $\mathrm{CaMgCl}$ type (Fig.5). 

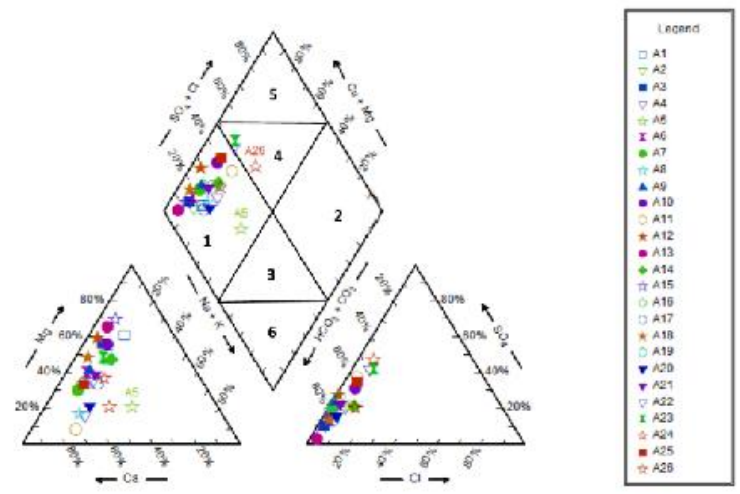

Figure 5: Pipers plot showing the chemical characteristics of ground water in Ifewara and Environs

The provenance of the chemical constituent of the water was also classified based on the meteoric gneiss index $\left(\mathrm{r}_{2}\right)$ using;

$$
r_{2=\left(\left(\mathrm{Na}^{+} \mathrm{K}^{+}\right)-\mathrm{Cl}^{+} / \mathrm{SO}_{4}^{2-}\right.}
$$

The meteoric gneiss index and the concentrations of $\mathrm{Na}^{+}, \mathrm{K}^{+}, \mathrm{SO}_{4}^{2-}$ and $\mathrm{Cl}^{-}$were expressed in meq/l. groundwater with $\mathrm{r} 2$ greater than $1(\mathrm{r} 2>1)$ suggest shallow meteoritic water percolation type while r2 $<1$ suggest a provenance of deep meteoric water percolation type. The meteoric gneiss values of all the sample were observed to be greater than 1 indicates they are from the shallow meteoric water percolation type. This can also be supported with the depth of all the hand dug wells ranging between 9.15 and $19.98 \mathrm{~m}$.

Gibbs ratio and plots are widely sued to assess the functional sources of the dissolved chemical constituents and it could be; precipitation dominance, rock dominance or evaporation dominance (Ramesh, 2012). The mechanism controlling the groundwater chemistry of the samples were observed to be precipitation and rock dominance (Fig. 4).

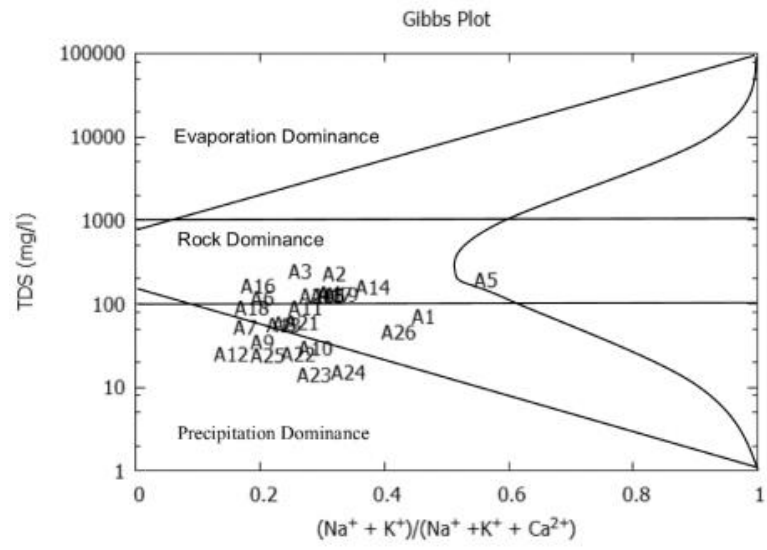

Figure 4: Plot of TDS against $\mathrm{Na} /(\mathrm{Na}+\mathrm{Ca})$ ratio (after Gibbs, 1970)

Two predominant water types were identified based on water classification $\mathrm{Ca}-\mathrm{Mg}-\mathrm{HCO}_{3}$ andMg-Ca- $\mathrm{CO}_{3}$ However, water samples A5 and A25 have water type $\mathrm{Ca}-\mathrm{Mg}-\mathrm{Cl}$ both having unusual abundance of $\mathrm{Cl}$. Possible source of the $\mathrm{Ca}-\mathrm{Mg}$ ions in the water could imply a provenance from plagioclase feldspars, mafic minerals and clays from the underlying weathered basement (Anudu, 2011).

\section{Irrigation water quality}

All ground water contains dissolved salts and trace elements which are from the process of weathering, erosion or effluent from Industries, municipal sewage or irrigated farmlands. The suitability of groundwater for irrigation depends upon the chemical composition of the water. For agricultural purposes, salinity levels in groundwater is a primary concern, since 
salt can affect soil structure and yield (Fipps, 2003). High salinity is capable of posing salinity hazard to plants by creating an artificial drought condition whereby the roots of plants are unable to absorb water even when the soil is well moistured. Salinity hazard can be measured using both conductivity and dissolved solids.
The effect of salinity hazard on plants can vary from low, medium, high to very high. Low salinity have no detrimental effects on plants; Medium salinity have detrimental effects to sensitive crops; High salinity, adverse effects on many crops and very high salinity are only suitable only for salt tolerant plants

Table 2: Salinity hazard (Rockware aq.QA, 2003)

\begin{tabular}{lll}
\hline & Conductivity $(\mathrm{mhos} / \mathrm{cm})$ & Dissolved solids $(\mathrm{mg} / \mathrm{L})$ \\
\hline Low salinity, no detrimental effects expected & $<250$ & $<200$ \\
Medium salinity, detrimental effects to sensitive crops & $250-750$ & $200-500$ \\
High salinity, adverse effects on many crops & $750-2250$ & $500-1500$ \\
Very high salinity, suitable only for salt tolerant plants & $2250-5000$ & $1500-3000$
\end{tabular}

Sodium adsorption ratio (SAR) is the most important chemical parameter for determining the suitability of the groundwater for irrigation purposes and it was calculated using;

$$
S A R=\frac{\left[\mathrm{Na}^{+}\right]}{\sqrt{\frac{\left[\mathrm{Ca}^{2+}\right]+\left[\mathrm{Mg}^{2+}\right]}{2}}}
$$

Salinity hazard of the ground water in the study based on the SAR vary between 0.12 and 1.67 which shows that $62 \%$ of the water samples in the study area was observed to have Low values while $38 \%$ have high SAR values. (Table 2).

\section{CONCLUSION}

Hydrochemistry evaluation suggest the cations in the water are from plagioclase feldspars, mafic minerals and clays in the weathered basement aquifer. Results from the study shows that the water in Ifewara and environ is safe for drinking with a low salinity hazard making it suitable for irrigation purposes. The water chemistry was observed to have been strongly influenced by dilution and weathering processes at shallow depth.

\section{ACKNOWLEDGEMENT}

The author acknowledges the assistance of the residents of Ifewara community for giving access to their wells. The efforts of Laboratory Staff of EMT, FUNAAB in carrying out the laboratory analysis is also much appreciated

\section{REFERENCES}

Anudu, G. K., Obrike, S. E., Onuba, L. N and Ikpokonte, A. E., 2011. Hydro-Geochemical Evaluation of Groundwater Resources from Hand Dug wells around Kakuri and its Environs, Kaduna State, Northcentral Nigeria. Journal of Mining and geology, 47, (2): 75-85.

Bouwer, H., 2002. Artificial recharge of groundwater: Hydrology and engineering. Hydrogeology Journal, 10, (2): 121-142.
Buchanan, T. J., 1983. International water technology conference and exposition (AUGA Expo 83) Acapulco, Mexico

Fipps, G., 2003. Irrigation Water Quality Standards and Salinity Management Strategies, Texas FARMER Collections

Gbadebo, A., Oyedepo, J and Taiwo, A., Variability of nitrate in groundwater in some parts of southwestern Nigeria, The Pacific Journal of Science and Technology, 11, (2010) 572-584.

Gibbs, R. J., 1970. Mechanism controlling world water chemistry science, $170: 1088-1090$

Piper, A. M., 1994. A graphic procedure in the geochemical interpretation of water analysis. Trans. America Geophysical Union, 25, 914923.

Ramesh, K and Bhuvana, J. P., 2012. Hydrochemical characteristics of groundwater for domestic and irrigation purposes in Periyakulam Taluk of Theni District, Tamil Nadu. I research Journal of Environmental Sciences, 1, 19-27.

Saijad, M. M., Rahaim, S and Tahir, S.S., 1998. Chemical quality of groundwater in Rawalpindi/Islamabad Pakistan $24^{\text {th }}$ WEDC CONFERENCE, Islamabad, Pakistan.

Valoon, G. W and Duffy, S. J., 2005. The Hydrosphere. In: Environmental Chemistry: A Global Perspective. $\quad 2^{\text {nd }} E d n$. New York: Oxford University Press. Pp: 197-211.

World Health Organization (WHO)., 2006. Guidelines for drinking water quality, Vol. 1, Recommendations, Geneva, Switzerland. 
